\title{
Androgen Receptor Mutations
}

\author{
A. O. Brinkmann, ${ }^{1 \star}$ G. Jenster, ${ }^{1}$ C. Ris-Stalpers, ${ }^{1}$ \\ J. A. G. M. van der Korput, ${ }^{2}$ H. T. Brüggenwirth, ${ }^{1}$ \\ A. L. M. Boehmer ${ }^{1}$ and J. Trapman' \\ Departments of ${ }^{1}$ Endocrinology and Reproduction and ${ }^{2}$ Pathology, Erasmus University, Rotterdam, The Netherlands
}

Male sexual differentiation and development proceed under direct control of androgens. Androgen action is mediated by the intracellular androgen receptor, which belongs to the superfamily of ligand-dependent transcription factors. At least three pathological situations are associated with abnormal androgen receptor structure and function: androgen insensitivity syndrome (AIS), spinal and bulbar muscular atrophy (SBMA) and prostate cancer. In the $\mathrm{X}$-linked androgen insensitivity syndrome, defects in the androgen receptor gene have prevented the normal development of both internal and external male structures in 46,XY individuals. Complete or gross deletions of the androgen receptor gene have not been found frequently in persons with complete androgen insensitivity syndrome. Point mutations at several different sites in exons 2-8 encoding the DNAand androgen-binding domain, have been reported for partial and complete forms of androgen insensitivity. A relatively high number of mutations were reported in two different clusters in exon 5 and in exon 7. The number of mutations in exon 1 is extremely low and no mutations have been reported in the hinge region, located between the DNA-binding domain and the ligand-binding domain and which is encoded by the first half of exon 4. Androgen receptor gene mutations in prostate cancer are very rare and are reported only in exons 4-8. The $X$-linked spinal and bulbar muscle atrophy (SBMA; Kennedy's disease) is associated with an expanded length ( $>40$ residues) of one of the polyglutamine stretches in the N-terminal domain of the androgen receptor.

7. Steroid Biochem. Molec. Biol., Vol. 53, No. 1-6, pp. 443-448, 1995

\section{INTRODUCTION}

Androgens (testosterone and $5 \alpha$-dihydrotestosterone) play a crucial role in several stages of male development (e.g. sexual differentiation, initiation and maintenance of spermatogenesis and of secondary male characteristics, feedback regulation of gonadotrophin secretion) [1]. Androgens act in their target cells via an interaction with the androgen receptor resulting in direct regulation of gene expression. The androgen receptor belongs to a large family of DNA-binding zinc-finger proteins, which also includes the other steroid hormone receptors, the thyroid hormone receptors, the retinoid receptors and orphan receptors [2].

In X-linked androgen insensitivity syndrome, defects in the androgen receptor gene have prevented the normal development of both internal and external male structures in $46, \mathrm{XY}$ individuals. The rare $\mathrm{X}$-linked spinal and bulbar muscular atrophy is characterized by

Proceedings of the IX International Congress on Hormonal Steroids, Dallas, Texas, U.S.A., 24-29 September 1994.

^Correspondence to A. O. Brinkmann. a progressive degeneration of motor neurons and is sometimes associated with signs of androgen insensitivity and infertility [3]. Limited information is available on abnormal androgen receptors in prostate cancer [4-8].

The information on the molecular structure of the human androgen receptor has facilitated the study of molecular defects associated with androgen insensitivity, SBMA and prostate cancer.

\section{ANDROGEN RECEPTOR ABNORMALITIES}

In this overview we will focus on the molecular structure of the androgen receptor in subjects with androgen insensitivity syndrome, in patients with Kennedy's syndrome (X-linked spinal and bulbar muscular atrophy), in a prostate cancer cell line (LNCaP) and in a tumor specimen obtained from patients with prostate cancer. Throughout the text, the numbering of the different codons is based on a total number of 910 amino acid residues in the human androgen receptor (20 glutamine and 16 glycine residues). 


\section{ANDROGEN RECEPTOR ABNORMALITIES IN THE ANDROGEN INSENSITIVITY SYNDROME}

Only a few cases have been reported with partial or complete deletion of the androgen receptor gene, indicating the relative low frequency of this type androgen receptor defect [9]. Most individuals in the reported cases are completely androgen resistant. There has been no report on possible mutations in the androgen receptor promoter region or in the $5^{\prime}$ - and $3^{\prime}$-untranslated regions of the gene.

The N-terminal domain of the human androgen receptor is characterized by the presence of several homopolymeric amino acid stretches, e.g. three polyglutamine stretches with different lengths; a long polyglycine stretch; a polyproline stretch of eight residues and a polyalanine stretch of five residues [10]. The length of the longest polyglutamine repeat varies in different normal individuals from 12 to 32 residues, with a high frequency of $20-22$ residues $[11,12]$ (see also Fig. 1). This type of polymorphism offers the possibility of linkage studies in families with supposed defective androgen receptors.

We have detected a single nucleotide insertion (codon 42, $\mathrm{C}$ insertion) and a single nucleotide deletion (codon 263, A deletion) in exon 1 in individuals with complete androgen insensitivity syndrome (Fig. 2). Both mutations caused frameshifts resulting in premature stopcodons at codon-positions 171 and 292, respectively. In both cases androgen receptor protein expression was undetectable. Another mutation in exon 1 resulted in a premature stopcodon at codon-position 439.

\section{Mutations in the DNA-binding domain}

Detailed structural information has been published on the crystal structure of the DNA-binding domain of the glucocorticoid receptor complexed with DNA [13]. This structural information might also be representative for the other members of the steroid/thyroid hormone receptor family, including the human androgen receptor. In total 18 different mutations in the DNA-binding domain (exons 2 and 3 ) have been

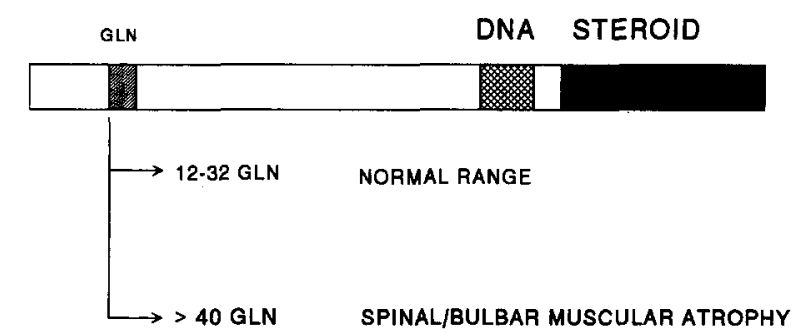

Fig. 1. Position of the glutamine (Gln) stretch in the aminoterminal domain of the human androgen receptor, which is susceptible to variation in normal individuals. The abnormal length of the Gln-stretch associated with the $\mathrm{X}$ linked spinal and bulbar muscular atrophy (SBMA) is also indicated.

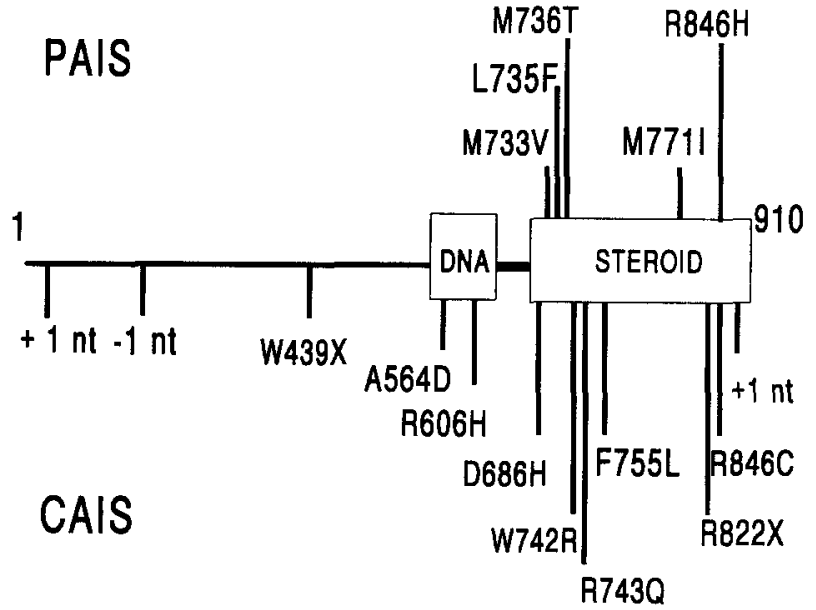

Fig. 2. Schematic representation of the localization of androgen receptor mutations detected in Rotterdam in patients with the complete (CAIS) and partial (PAIS) form of androgen insensitivity. Numbers and one letter codes indicate the position and the type of substitution of the mutated codons.

published (Fig. 3). Eight mutations were observed in the first zinc finger and ten in the second zinc finger.

In genital skin fibroblasts from a subject with the $\mathrm{X}$-linked Reifenstein syndrome (partial androgen insensitivity) we detected the presence of two mature androgen receptor transcripts; the wild-type transcript and a transcript in which exon 3 sequences were absent without disruption of the translational reading frame [23]. Sequence analysis showed a deletion of $>6 \mathrm{~kb}$ in intron 2 of the human androgen receptor gene ending $18 \mathrm{bp}$ upstream of exon 3 (Fig. 4). The deletion included the putative branch-point sequence but not the acceptor splice site on the intron 2 /exon 3 boundary. The deletion results in $92 \%$ aberrant splicing of wildtype transcript. The mutant transcript encodes an androgen receptor protein lacking the second zinc finger of the DNA binding domain. The mutant protein was expressed in genital skin fibroblasts of the patient. The residual $8 \%$ wild-type transcript could be the result of the use of a cryptic branch-point sequence located 63 bp upstream of the intron 2 /exon 3 boundary of the mutant gene. The mutant androgen receptor protein was not able to activate transcription and did not influence the transactivating properties of the wildtype androgen receptor. It is concluded that the partial androgen-insensitivity syndrome of this patient is the consequence of the limited amount of wild-type androgen receptor protein expressed in androgen target cells, resulting from the deletion of the intron 2 putative branch-point sequence. A complete deletion of exon 3 has been reported in a patient with complete androgen insensitivity [9].

\section{Mutations in the androgen binding domain}

Several functional and structural aspects have been ascribed to exon 4, which harbors part of a highly 

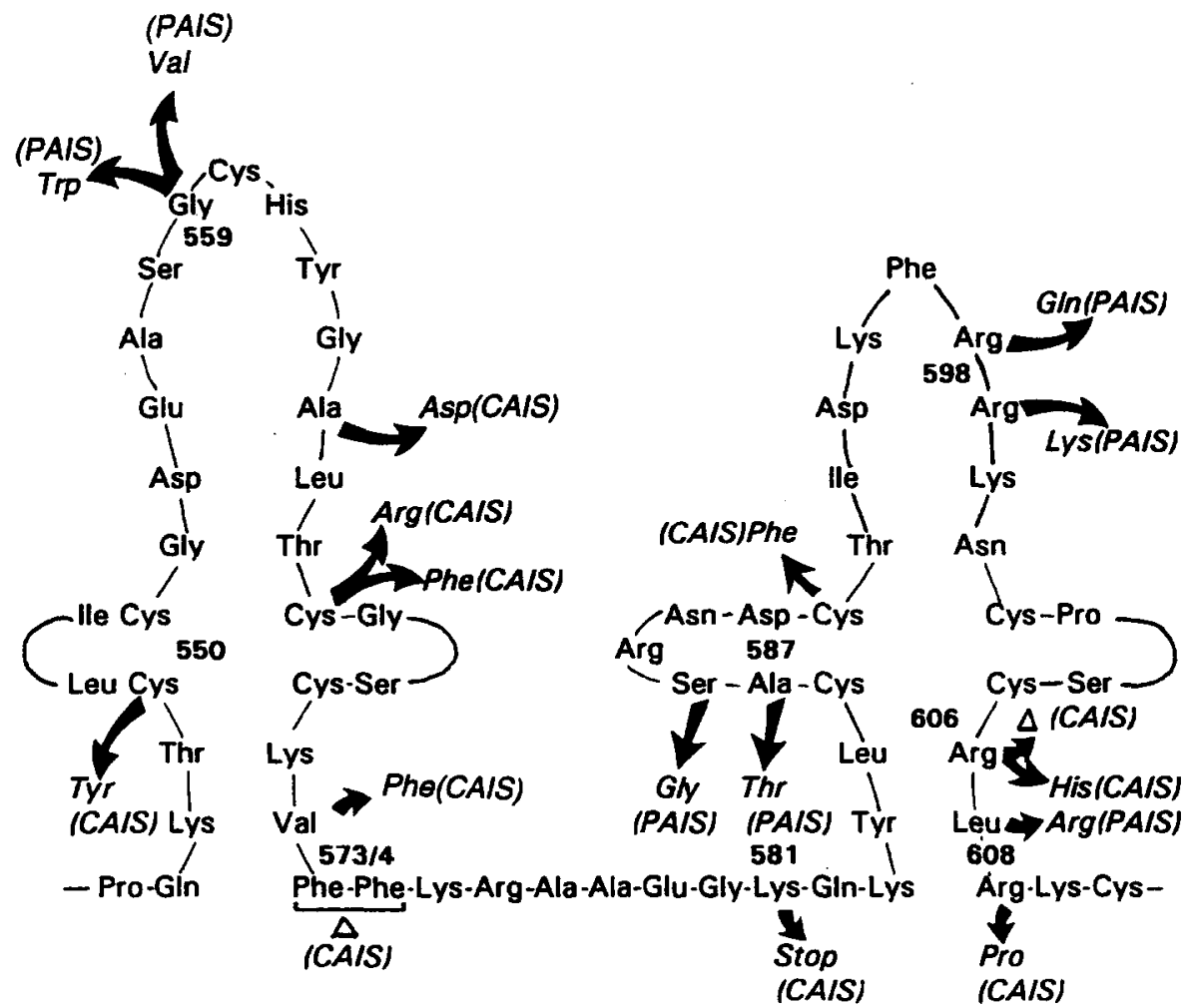

Fig. 3. Location of the different amino acid substitutions in the DNA-binding domain due to point mutations in exons 2 and 3 and two deletions of a codon $(\Delta)$ in the androgen receptor gene of individuals with complete (CAIS) or partial (PAIS) androgen insensitivity [refs 14-22 and unpublished observations].

conserved nucleoplasmin-like nuclear localization signal, the hinge region and part of the steroid binding domain [24]. Therefore mutations in exon 4 could affect different functions of the androgen receptor. All reported mutations to date in exon 4 are located in the part of the exon that encodes the $\mathrm{N}$-terminal region of the steroid binding domain.

We detected in the sequence of the androgen receptor gene from a person with the complete form of androgen insensitivity a $G$ to $T$ mutation on position 1 in the splice donor site of intron 4 [25]. The conse-

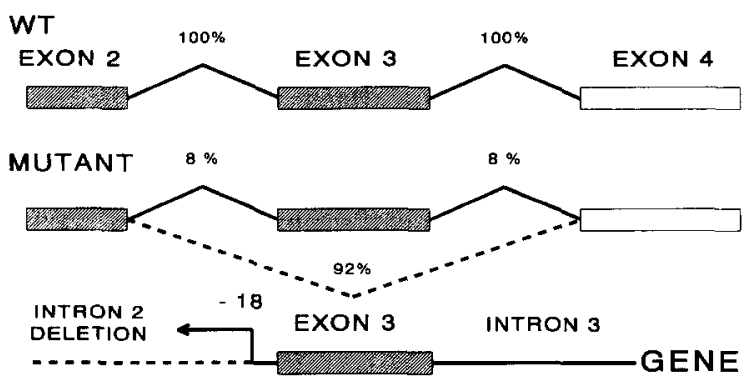

Fig. 4. Schematic illustration of exons $2-4$ of the human androgen receptor gene and of the alternative splicing event resulting from a partial intron 2 deletion in a patient with the $\mathrm{X}$-linked Reifenstein syndrome. The solid lines represent wild-type splicing events and the dashed line represents the aberrant splicing event [ref. 23]. quence of this point mutation was an abnormal androgen receptor mRNA splicing. Sequence analysis of the mutant fragment revealed the use of a cryptic splice donor site CAG/GTGTAG at position 2020/2021 in exon 4 of the human androgen receptor gene which is normally inactive. The use of this cryptic splice site results in the deletion of 123 nucleotides from the mRNA. Translation will consequently result in an in-frame deletion of 41 amino acid residues in the androgen receptor protein from this person. Transient expression of the mutant androgen receptor resulted in the synthesis of a protein which was approx. $5 \mathrm{kDa}$ smaller than the wild type receptor as determined by SDS-PAGE. The mutant receptor was unable to bind androgens and did not activate transcription of an androgen-regulated reporter gene construct [25].

In two unrelated individuals with the complete form of androgen insensitivity, two different point mutations were found by us at the same nucleotide in codon 686 (aspartic acid) of exon 4 [26] (Fig. 2). Both mutant androgen receptors displayed the same altered binding characteristics after transient expression as those measured in genital skin fibroblasts from the affected subjects. In co-transfection studies, using a glucocorticoid responsive element linked to the thymidine kinase promoter and to the chloramphenicol acetyl transferase gene (GRE-tk-CAT) as a reporter gene, both mutant receptors were devoid of any transactivation activity in 
the presence of physiological hormone concentrations [26].

Exon 5 forms an essential part of the steroid-binding domain of the androgen receptor. We detected 5 different mutations in exon 5 , of which the M733V and M736T mutations were found in patients with the partial form of the androgen insensitivity syndrome (Fig. 2). In exon 5 a total of 25 point mutations in 20 different codons have been reported. Two clusters of mutations can be localized in exon 5 between codons 723-732 and 740-757 in the androgen receptor gene of patients with the complete androgen insensitivity syndrome. We found three mutations (W742R; R743Q; F7551) located in the second cluster (Fig. 2).

The 10 reported mutations in exon 6 in 9 different codons have been found in androgen receptor genes from androgen insensitive individuals with the complete form ( 6 mutations) and the partial form (4 mutations) of the syndrome.

For exon 7 twelve mutations in eight different codons have been reported in persons with the complete androgen insensitivity syndrome, while 7 mutations were reported in the androgen receptor gene of persons with partial androgen insensitivity. In addition we detected in a patient with the complete syndrome an insertion of one nucleotide in codon 839 causing a frame-shift and resulting in a premature stopcodon (Fig. 2). From mutational analysis studies it is known that this kind of receptor truncation completely abolishes hormone binding and transcriptional activation [27].

In total ten mutations in exon 8 have been reported. Six mutations were found in subjects with the complete form of androgen insensitivity and 4 mutations in subjects with the partial form.

\section{ANDROGEN RECEPTOR ABNORMALITIES IN SPINAL AND BULBAR MUSCULAR ATROPHY} (SBMA)

A unique example of tissue specific effects of a defective androgen receptor is Kennedy's syndrome. This rare, $\mathrm{X}$-linked motor neuron disease becomes manifest in men between the age of 30 and 50 and is characterized by a progressive spinal and bulbar muscular atrophy associated with signs of androgen insensitivity and infertility [3]. The length of the polyglutamine stretch in the androgen receptor in all investigated Kennedy's syndrome patients ranges between 40 and 52 [11].

We have investigated the effect of an expanded polyglutamine stretch and also a completely deleted glutamine stretch on the transactivation function of the androgen receptor in a model system. For this purpose the androgen receptor constructs were expressed after cotransfection of COS cells with a reporter gene construct containing either the mouse mammary tumor virus promoter (MMTV) or the prostate-specific antigen (PSA) promoter [28]. In these experiments a 2-fold

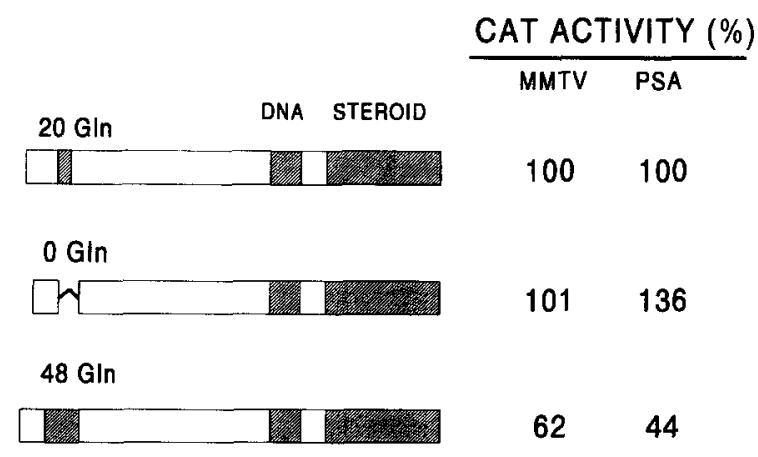

Fig. 5. Influence of the length of the polyglutamine-stretch on transcription activation by the human androgen receptor. Transcriptional activity was examined by co-transfection of androgen receptor expression plasmids and reporter plasmids containing either the MMTV promoter or the promoter of the prostate specific antigen gene (PSA) linked to the CAT-gene. CAT activity induced by the wild-type androgen receptor in the presence of $10 \mathrm{nM}$ methyltrienolone (R1881) was arbitrarily set at $100 \%$.

reduction in transcription activation was observed with both reporter-constructs and the androgen receptor with 48 glutamine residues (Fig. 5). Complete deletion of the glutamine stretch resulted in a significant increase in transcriptional regulation only with the PSAreporter construct. The differences could not be explained by differences in the level of receptor protein expression. In similar studies Mhatre $e t$ al. also found that an androgen receptor with an expanded polyglutamine stretch transactivates subnormally [29]. Whether a doubling of the length of the polyglutamine stretch directly affects motor neuron function is still unclear. Possibly a change in the structural constraint of the N-terminal domain could result in a modified interaction with motor neuron-specific transcription factors and consequently in an altered assembly of the transcription initiation complex.

\section{ANDROGEN RECEPTOR ABNORMALITIES IN PROSTATE CANCER}

It has long been speculated that mutations in the androgen receptor could play a role in the initiation or the progressive androgen-independent growth of prostate tumors. Previous studies have established that the human prostate carcinoma cell line $\mathrm{LNCaP}$ can be stimulated with respect to growth not only by androgens, but also by progesterone, R5020 (a synthetic progestagen) and oestradiol [30]. Characterization of the androgen receptor in these cells revealed an altered steroid binding specificity with an increased preference for progestagens and oestradiol as compared with the steroid binding specificity of the androgen receptor in normal cells [31]. These data strongly suggested a modification of the androgen receptor and particularly in the steroid-binding domain. Sequence analysis revealed one point mutation in codon 868 in exon 8 


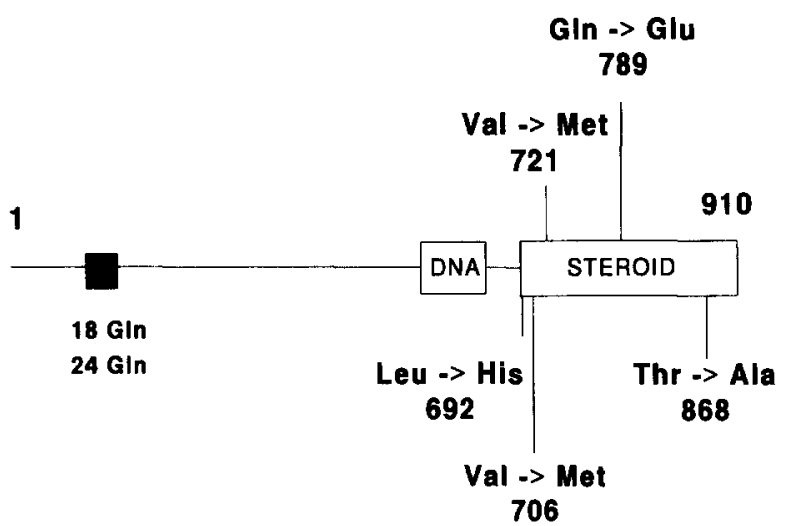

Fig. 6. Location of androgen receptor mutations published in prostate cancer. Numbers and one letter codes refer to the position and the type of substitution of the mutated codons [refs $4,5,7,32]$.

located at the C-terminal end of the steroid binding domain [32] (Fig. 6). The mutation $(A \rightarrow G)$ resulted in a threonine $\rightarrow$ alanine substitution. To determine whether the substitution affects the functional properties of the LNCaP androgen receptor, the mutant cDNA was cloned in an expression vector and transiently expressed in COS-1 and HeLa cells. In the transfection studies, the mutant receptor displayed increased binding affinity for progestagens and oestradiol. In addition, these ligands activate transcription at concentrations which are not sufficient for activation of the wild-type androgen receptor. These results confirm that the observed point mutation in the $\mathrm{LNCaP}$ androgen receptor is the cause of the broad steroid binding specificity. Whether such a point mutation, which changes the steroid binding specificity, can play a role in progressive prostate tumor growth remains to be established.

Analysis of the structure of the androgen receptor in 27 DNA samples of patients with progressively advancing prostate cancer did not result in the detection of mutations [6]. In similar studies by others, three different point mutations were detected in the steroid binding domain $[4,5,7]$ (Fig. 5). In one case the amino acid substitution resulted in an altered steroid binding specificity similarly as was found for the LNCaP cell androgen receptor [5]. The same mutation as found in the LNCaP cell androgen receptor has been reported in metastatic tissues from a prostate cancer patient [7]. Also a variation in the polymorphic glutamine-stretch has been reported in tumor tissue from a prostate cancer patient [8]. It can be concluded that, although the androgen receptor is one of the key molecules in prostate development, the mutations of the receptor do not substantially contribute to aberrant cell growth in the case of prostate cancer.

Acknowledgements-The authors thank T. Hoogenboezem, M. C. T. Verleun-Mooijman, P. E. de Ruiter and E. Kamst for excellent technical assistance during the different investigations. These investigations were supported by the Netherlands Organization for Scien- tific Research (NWO), by the Sophia Foundation for Medical Research and by the Dutch Cancer Society.

\section{REFERENCES}

1. Griffin J. E. and Wilson J. D.: The androgen resistance syndromes: $5 \alpha$-reductase deficiency, testicular feminization and related disorders. In The Metabolic Basis of Inherited Disease. 6th Edition (Edited by C. R. Scriver, A. L. Baudet, W. L. Sly and D. Valle). McGraw-Hill, NY, (1989) Vol. II, pp. 1919-1944.

2. Evans R. M.: The steroid and thyroid hormone receptor superfamily. Science 240 (1988) 889-895.

3. Warner C. L., Griffin J. E., Wilson J. D., Jacobs L. D., Murray K. R., Fischbeck K. H., Dickoff D. and Griggs R. C.: X-linked spinomuscular atrophy: a kindred with associated abnormal androgen receptor binding. Neurology 42 (1992) 2181-2184.

4. Newmark J. R., Haldy D. O., Tonb D. C., Carter B. S., Epstein J. I., Isaacs W. B., Brown T. R. and Barrack E. R.: Androgen receptor gene mutations in human prostate cancer. Proc. Natn. Acad. Sci. U.S.A. 173 (1992) 6319-6323.

5. Culig Z., Hobisch A., Cronauer M. V., Cato A. C. B., Hittmair A., Radmayr C., Eberle J., Bartsch G. and Klocker H.: Mutant androgen receptor detected in an advanced-stage prostatic carcinoma is activated by adrenal androgens and progesterone. Molec. Endocr. 7 (1993) 1541-1550.

6. Ruizeveld de Winter J. A., Janssen P. J. A., Sleddens H. F. B. M., Verleun-Mooijman M. C. T., Trapman J., Brinkmann A. O., Santerse B., Schroeder F. H. and Van der Kwast Th. H.: Androgen receptor status in localized and locally progressive hormone refractory human prostate cancer. Am. 7. Path. 144 (1994) $735-746$

7. Suzuki H., Sato N., Watabe Y., Masai M., Seino S. and Shimazaki J.: Androgen receptor gene mutations in human prostate cancer. 7. Steroid Biochem. Molec. Biol. 46 (1993) 759-765.

8. Schoenberg M. P., Hakimi J. M., Wang S., Bova G. S., Epstein J. l., Fischbeck K. H., Isaacs W. B., Walsh P. C. and Barrack E. R.: Microsatellite mutation $\left(\mathrm{CAG}_{24-18}\right)$ in the androgen receptor gene in human prostate cancer. Biochem. Biophys. Res. Commun. 198 (1994) 74-80.

9. French F. S., Lubahn D. B., Brown T. R., Simental J. A., Quigley C. A., Yarbrough W. G., Tan J-A., Sar M., Joseph D. R., Evans B. A. J., Hughes I. A., Migeon C. J. and Wilson E. M.: Molecular basis of androgen insensitivity. Rec. Prog. Horm. Res. 46 (1990) 1-42.

10. Faber P. W., Kuiper G. G. J. M., van Rooij H. C. J., van der Korput J. A. G. M., Brinkmann A. O. and Trapman J.: The $\mathrm{N}$-terminal domain of the human androgen receptor is encoded by one, large exon. Molec. Cell. Endocr. 61 (1989) 257-262.

11. La Spada A. R., Wilson E. M., Lubahn D. B., Harding A. E. and Fischbeck K. H.: Androgen receptor gene mutations in $\mathrm{X}$-linked spinal and bulbar muscular atrophy. Nature 352 (1991) $77-79$.

12. Sleddens H. F. B. M., Oostra B. A., Brinkmann A. O. and Trapman J.: Trinucleotide repeat polymorphism in the androgen receptor gene (AR). Nucl. Acids Res. 20 (1991) 1427

13. Luisi B. F., Xu W. X., Otwinowski Z., Freedman I. P., Yamamoto K. R. and Sigler P. B.: Crystallographic analysis of the interaction of the glucocorticoid receptor with DNA. Nature 352 (1991) 497-505.

14. Zoppi S., Marcelli M., Deslypere J-P., Griffin J. E., Wilson J. D. and McPhaul M. J.: Amino acid substitutions in the DNAbinding domain of the human androgen receptor are a frequent cause of receptor-binding positive androgen resistance. Molec. Endocr. 6 (1992) 409-415.

15. Chang Y. T., Migeon C. J. and Brown T. R.: Program of the 73rd Annual Meeting of the Endocrine Society, Washington DC (1991) Abstract 28 .

16. Marcelli M., Tilley W. D., Wilson C. M., Griffin J. E., Wilson J. D. and McPhaul M. J.: Definition of the human androgen receptor gene permits the identification of mutations that cause androgen resistance: premature termination of the receptor protein at amino acid residue 588 causes complete androgen resistance. Molec. Endocr. 4 (1990) 1105-1116.

17. Klocker H., Kaspar F., Eberle J., Uberreiter S., Radmayr C. and Bartsch G.: Point mutation in the DNA binding domain of the 
androgen receptor in two families with Reifenstein syndrome. Am. F. Hum. Genet. 50 (1992) 1318-1327.

18. Wooster R., Mangion J., Eeles R., Smith S., Dowsett M., Averill D., Barrett-Lee P., Easton D. F., Ponder B. A. J. and Stratton M. R.: A germline mutation in the androgen receptor gene in two brothers with breast cancer and Reifenstein syndrome. Nature Gen. 2 (1992) 132-134.

19. Saunders P. T. K., Padayachi T., Tincello D. G., Shalet S. M. and Wu F. C. W.: Point mutations detected in the androgen receptor gene of three men with partial androgen insensitivity syndrome. Clin. Endocr. 37 (1992) 214-220.

20. De Bellis A., Quigley C. A., Cariello N. F., Ho K. C. and French F. S.: Program of the 73rd Annual Meeting of the Endocrine Society, Washington DC (1991) Abstract 1141.

21. Marcelli M., Zopi S., Grino P. B., Griffin J. E., Wilson J. D. and McPhaul $M$. J.: A mutation in the DNA-binding domain of the androgen receptor gene causes complete testicular feminization in a patient with receptor-positive androgen resistance. f. Clin. Invest. 87 (1991) 1123-1126.

22. Beitel L. K., Prior L., Vasiliou D. M., Gottlieb B., Kaufman M., Lumbroso R., Alvarado C., McGillivray B., Trifiro M. and Pinsky L.: Complete androgen insensitivity due to mutations in the probable $\alpha$-helical segments of the DNA-binding domain in the human androgen receptor. Hum. Molec. Genet. 3 (1994) 21-27.

23. Ris-Stalpers C., Verleun-Mooijman M. C. T., de Blaeij T. J. P., Degenhart H. J., Trapman J. and Brinkmann A. O.: Differential splicing of human androgen receptor pre-mRNA in X-linked Reifenstein syndrome, because of a deletion involving a putative branch site. Am. F. Hum. Genet. 54 (1994) 609-617.

24. Jenster G., Trapman J. and Brinkmann A. O.: Nuclear import of the human androgen receptor. Biochem. F. 293 (1993) $761-768$.

25. Ris-Stalpers C., Kuiper G. G. J. M., Faber P. W., Schweikert H. U., van Rooij H. C. J., Zegers N. D., Hodgins M. B., Degenhart H. J., Trapman J. and Brinkmann A. O.: Aberrant splicing of androgen receptor mRNA results in synthesis of a nonfunctional receptor protein in a patient with androgen insensitivity. Proc. Natn. Acad. Sci. U.S.A. 87 (1990) $7866-7870$.

26. Ris-Stalpers C., Trifiro M. A., Kuiper G. G. J. M., Jenster G., Romalo G., Sai T., van Rooij H. C. J., Kaufman M., Rosenfield R. L., Liao S., Schweikert H. U., Trapman J., Pinsky L. and Brinkmann A. O.: Substitution of aspartic acid -686 by histidine or asparagine in the human androgen receptor leads to a functionally inactive protein with altered hormone-binding characteristics. Molec. Endocr. 5 (1991) 1562-1569.

27. Jenster G., van der Korput J. A. G. M., van Vroonhoven C., van der Kwast Th. H., Trapman J. and Brinkmann A. O.: Domains of the human androgen receptor involved in steroid binding, transcriptional activation, and subcellular localization. Molec. Endocr. 5 (1991) 1396-1404.

28. Riegman P. H. J., Vlietstra R. J., Van der Korput J. A. G. M., Brinkmann A. O. and Trapman J.: The promoter of the prostatespecific antigen gene contains a functional androgen responsive element. Molec. Endocr. 5 (1991) 1921-1930.

29. Mhatre A. N., Trifiro M. A., Kaufman M., Kazemi-Esfariani P., Figlewicz D., Rouleau G. and Pinsky L.: Reduced transcriptional regulatory competence of the androgen receptor in Xlinked spinal and bulbar muscular atrophy. Nature Genet. 5 (1993) 184-188

30. Schuurmans A. L. G., Bolt J., Voorhorst M., Blankenstein M. A. and Mulder E.: Regulation of growth and epidermal growth factor receptor levels of $\mathrm{LNCaP}$ prostate tumor cells by different steroids. Int. F. Cancer 42 (1988) 917-922.

31. Veldscholte J., Voorhorst-Ogink M. M., Bolt-de Vries J., van Rooii H. C. J., Trapman J. and Mulder E.: Unusual specificity of the androgen receptor in the human prostate tumor cell line LNCaP: high affinity for progestagenic and estrogenic steroids. Biochim. Biophys. Acta 1052 (1990) 187-194.

32. Veldscholte J., Ris-Stalpers C., Kuiper G. G. J. M., Jenster G., Berrevoets C., Claassen E., van Rooij H. C. J., Trapman J., Brinkmann A. O. and Mulder E.: Biochem. Biophys. Res. Commun. 173 (1990) 534-540. 